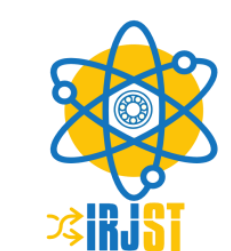

Available online at https://www.irjst.com/

International Research Journal of Science and Technology

ISSN: 2707-3955

DOI: https://doi.org/10.46378/irjst.2020.010304

\title{
Appraisal of the Control of Industrial Policies to the Digital Economy: Proof from Tanzania
}

\section{Nuhu Sansa}

Guangxi University, Economics Department, Nanning, China

\begin{tabular}{llll}
\multicolumn{2}{l}{ Paper Status } & & \\
Received : & Apr 2020 \\
Accepted & $:$ & May 2020 \\
Published & $:$ & Jun 2020
\end{tabular}

Key Words

Digital Economy

Industrial Policies

Tanzania

\begin{abstract}
Recent in Tanzania evidence show that the rapid technology advancement resulted to the high and significant contribution to the Gross domestic product and economic development. Allude to that fact; the interrogation of policy infrastructure particularly industrial policies to pilot the digital economy is inescapable. The contemporary study is determined to explore the control of industrial policies to the digital economy specifically macroeconomic digital variables employed by the study (Information and Technology Gross Domestic Product and Population Using Internet) during the period from 2010 to 2017 in Tanzania. With respect to that, simple regression model is applied to inquire into the control of industrial policies to the digital economy in Tanzania during the period from 2010 to 2017. Ascribable to the sparseness of data, the only data accessible for the study during the period from 2010 to 2017 were gathered from the World Bank and the Bank Of Tanzania Annual Reports. Straight to investigate the control of industrial policies to the digital economy in Tanzania during the period from 2010 to 2017, industrial policies were represented by the economic openness which be positioned independent variable, while Information and Technology Gross Domestic Product and Population Using Internet were dependent variables in the study. The information discovered in the study was in actual fact catching the attention. Information discovered as a result of the exploration shows that the relationship between economic openness and all digital macroeconomic variable applied by the study (Information and Technology Gross Domestic Product and Population Using Internet) is Negative and meaningless. To such a degree industrial policies had no control to the digital economy during the period from 2010 to 2017 in Tanzania.
\end{abstract}

Copyright (c) 2020: Nuhu Sansa. This is an open access distribution, and reproduction in any medium, provided Access article distributed under the Creative Commons Attribution License the original work is properly cited License, which permits unrestricted use.

Citation: Nuhu Sansa. "Appraisal of the Control of Industrial Policies to the Digital Economy: Proof from Tanzania". International Research Journal of Science and Technology, 1 (3), 215-220, 2020.

\section{Introduction}

Digital Economy mainly defined as the economy contributed by the income generated from the use of advanced technological such as the income generated from the population by using the internet, electronic payments, electronic finance, information and communication in general. Industrial policies are government policies aligned to pilot the manufacturing sector particularly its core functions including the

\footnotetext{
* Corresponding Author: Nuhu Sansa

Guangxi University, Economics Department, Nanning, China Email: nuhusansa09@gmail.com
}

production process, marketing and selling of the industries produced final goods aiming to speed up quick economic development and achieving industrialization status.

Tanzania government current is undertaking industrialization as a government top main agenda for economic development and transformation of the entire economy. Initiatives have been done to create, launch and implement industrial policies from the year of 1996, however the recent rapid technology advancement in the world take the country into the position to review industrial policies to reflect and support the digital economy. 
The World acquaintance is with the swiftly advancement of technology which coincide with expeditious growth of the digital economy. Allude to that fact, the interrogation of policy infrastructure particularly industrial policies to pilot the digital economy is inescapable. From this current economic debate, for sustainable digital economy industrial policies should be set to cover and pilot the digital economy associating with digital policies and investment policies objectively to achieve the desired goals.

From the current economic debate, where digital economy become vital for economic development and industrial policies should be set to pilot the digital economy, the fundamental question from whether Industrial policies have control or influence to the digital economy happen. Tanzania despite implementation of Industrial Policies since the year of 1996, no studies have been undertaken to evaluate the control of these policies to the digital economy. The contemporary study is determined to explore the control of industrial policies to the digital economy specifically macroeconomic digital variables employed by the study (Information and Technology Gross Domestic Product and Population Using Internet) during the period from 2010 to 2017 in Tanzania.

\subsection{Motivation of the Study and Objectives}

Recent in Tanzania evidence show that the rapid technology advancement resulted to the high and significant contribution to the Gross domestic product and economic development. The economic contribution of the mobile industry will increase in both absolute and relative terms, from $\$ 2.5$ billion in 2016 to more than $\$ 4$ billion in 2020 , accounting for more than $6 \%$ of GDP. The majority of this increase will be driven by improved productivity, particularly from the increasing adoption of mobile broadband services [1]. Wider network coverage and the rapid adoption of new $4 \mathrm{G}$ services could further accelerate growth and, subsequently, the mobile industry's contribution to economic growth.

Notwithstanding the fact that in Tanzania technological advancement resulted to the high contribution of Gross Domestic Product and economic development, in addition the present economic debate of Industrial policies to be set to reflect and support the digital economy, In Tanzania no studies have been done to investigate the control of industrial policies to the digital economy. The contemporary study is determined to explore the control of industrial policies to the digital economy specifically macroeconomic digital variables employed by the study (Information and Technology Gross Domestic Product and Population Using Internet) during the period from 2010 to 2017 in Tanzania.
From existing literature this study has never been done, and most important it answers the question concern the control of Tanzania industrial policies to the digital economy. The study generates new knowledge showing that the relationship between economic openness and all digital macroeconomic variable applied by the study (Information and Technology Gross Domestic Product and Population Using Internet) is Negative and meaningless during the period from 2010 to 2017 in Tanzania. To such a degree industrial policies had no control to the digital economy during the period from 2010 to 2017 in Tanzania.

The objective of the study is to investigate the control of industrial policies to the digital economy specifically macroeconomic digital variables employed by the study (Information and Technology Gross Domestic Product and Population Using Internet) during the period from 2010 to 2017 in Tanzania.

\section{Literature Review}

Different studies highlight the rise of national digital policies and explore the role of industrial policies to pilot the digital economy. Growth of national digital policies and highlight are how the industrial policy objectives important drivers of digital strategies[2].

The Tanzania Industry sector despite the implementation of industrial policies since the year of 1996 still the sector is not productive and not brought favorable outcome as expected for the history of Tanzania. It was highlighted the matter stated that, "Tanzania ranks among the leading stars of the 'African growth miracle', but a sector that has been largely absent from the Tanzania success story is industry"'[3].

Digital platforms and related technologies offer some potential for increasing efficiency and competition in the transport market [4]. As Tanzania gears towards its vision of becoming a middle-income economy by 2025, the National Five-Year Development Plan 2016/17-2020/21 (FYDP II), published in 2016, identifies industrialization as the main policy objective and key driver of economic transformation [5].

The economic contribution of the mobile industry will increase in both absolute and relative terms, from $\$ 2.5$ billion in 2016 to more than $\$ 4$ billion in 2020, accounting for more than $6 \%$ of GDP [1]. World acquaintance with the swiftly advancement of technology which coincide with expeditious growth of the digital economy. Allude to that fact; the interrogation of policy infrastructure particularly industrial policies to pilot the digital economy is inescapable. From the current economic debate, where digital economy become vital for economic development and industrial policies should be set to 
pilot the digital economy, the fundamental question from whether Industrial policies have control or influence to the digital economy happen. Since the adoption of the Arusha Declaration in 1967, Tanzania has charted a course for its industrial development within the framework of the economic and social objectives of equality, socialism and self-reliance [6].

It is undeniable fact that manufacturing sector plays key role in growth of any economy and it is from these sector developing countries can catch-up with the rest of the world [7]. Successful industrial policies need to be accompanied by reliable energy policies especially in a country like Tanzania, which is among the least electrified countries in the world [8]. This article explores Tanzania's experience of industrial policy since independence through the concept of the political settlement. Higher growth in manufacturing since 1996 has been seen as a vindication of neoliberal policies of market liberalization [9].

\section{Experimental Procedures, Materials and Methods.}

\subsection{Data and Methodology}

The contemporary study is determined to explore the control of industrial policies to the digital economy specifically macroeconomic digital variables employed by the study (Information and Technology Gross Domestic Product and Population Using Internet) during the period from 2010 to 2017 in Tanzania. Simple regression model in Double Log and Semi Log Linear Models employed as a methodology to probe the control of industrial policies to the digital economy during the period from 2010 to 2017 in Tanzania. Ascribable to the sparseness of data, the only data accessible for the study during the period from 2010 to 2017 were gathered from the World Bank and the Bank of Tanzania Annual Reports.

Straight to investigate the control of industrial policies to the digital economy in Tanzania during the period from 2010 to 2017, industrial policies were represented by the economic openness which be positioned independent variable, while Information and Technology Gross Domestic Product and Population Using Internet were dependent variables in the study. To evaluate the control of industrial policies to the digital economy the study used quantitative approach accompanied with the Excel (Microsoft office excel 2007) EVIEWS (3.0 style).

To scrutinize the control of industrial policies to the digital economy during the period from 2010 to 2017 in Tanzania, the study fabricates into reality the following equations:

The control of industrial policies to Information and Communication Gross Domestic Product:
TzICGdp $=$ A + M + B1..................(1) Where, TzICGdp is the natural log for Tanzania Information and Communication Gross Domestic Product, $\mathrm{M}$ is economic openness index, A is constant, and B1 is coefficient parameter.

The control of industrial policies to the Population Using Internet in Tanzania:

TzPUI $=\mathrm{A}+\mathrm{M}+\mathrm{B} 1 \ldots \ldots \ldots \ldots \ldots \ldots \ldots$............ Where, TzPUI is the natural log for Tanzania Population Using Internet, $\mathrm{M}$ is economic openness index, $\mathrm{A}$ is constant, and $\mathrm{B} 1$ is coefficient parameter.

\section{Results and Discussion}

The immediate study after congregating all the information required for evaluation, descriptive and analytical approach were applied to explore the control of industrial policies to the digital economy during the period from 2010 to 2017 in Tanzania.

To evaluate the control of industrial policies to the digital economy the study used quantitative approach accompanied with the Excel (Microsoft office excel 2007) EVIEWS (3.0 style).

\subsection{The Correlation between Industrial Policies and Digital Macro Economic Variables}

Straight to investigate the control of industrial policies to the digital economy in Tanzania during the period from 2010 to 2017, industrial policies were represented by the economic openness which be positioned independent variable, while Information and Technology Gross Domestic Product and Population Using Internet were dependent variables in the study.

\subsection{The Control of Industrial Policies to Information and Communication Gross Domestic Product during the Period from 2010 to 2007 In Tanzania}

Information discovered as a result of the investigation shows that relationship between Economic openness and Information and Communication Gross Domestic Product is negative and meaningless during the period from 2010 to 2017 in Tanzania . The results show the multiplier of Economic Openness is -0.2798 , which means the relationship between Economic openness and Information and Communication Gross Domestic Product is insignificant in Tanzania. Therefore Industrial policies had no control to Information and Communication Gross Domestic Product during the period from 2010 to 2017 in Tanzania. 
Appendix 1: Original data from the World Bank and Bank Of Tanzania Annual Report that are; economic openness index, and digital macroeconomic variables (Population Using Internet and Information and Communication Gross Domestic Product) of Tanzania during the period from 2010 to 2017.

\begin{tabular}{llllll}
\hline Y & EOI & PUI & G-ICTM & G-ICZN & T-GIC \\
\hline 2010 & 47.64 & 2.9 & 2.6 & 0.7 & 3.3 \\
2011 & 56.16 & 3.2 & 2.4 & 0.4 & 2.8 \\
2012 & 54.37 & 3.95 & 2.4 & 0.8 & 3.2 \\
2013 & 48.63 & 4.4 & 2.3 & 1.3 & 3.6 \\
2014 & 45.35 & 7 & 2.1 & 5.4 & 7.5 \\
2015 & 40.75 & 20 & 2 & 5.3 & 7.3 \\
2016 & 35.42 & 13 & 2 & 5 & 7 \\
2017 & 32.23 & 25 & 2 & 4.5 & 6.5 \\
\hline
\end{tabular}

$\begin{array}{llllll}\text { TOTAL } & 360.5 & 79.45 & 17.8 & 23.4 & 41.2\end{array}$

Where by : Y is Year, EOI is Economic Openness Index, PUI is Population Using Internet, G-ICTM is Information and Communication Gross Domestic Product Tanzania Main Land, G-ICNZ is Information and Communication Gross Domestic Product Tanzania Island (Zanzibar), T-GIC is Total of Information and Communication from Tanzania Mainland and Island.

Appendix2: Natural Logarithms Figures Computations originated from Appendix 1.

\begin{tabular}{llll}
\hline Y & EOI & PUI & T-GIC \\
\hline 2010 & 3.86 & 1.06 & 1.19 \\
2011 & 6.34 & 1.16 & 1.03 \\
2012 & 4 & 1.37 & 1.16 \\
2013 & 3.88 & 1.48 & 1.28 \\
2014 & 3.81 & 1.95 & 2.01 \\
2015 & 3.71 & 3 & 1.99 \\
2016 & 3.57 & 2.56 & 1.95 \\
2017 & 3.47 & 3.22 & 1.87 \\
\hline TOTAL & 32.64 & 15.8 & 12.48 \\
\hline
\end{tabular}

Where by : Y is Year, EOI is Economic Openness Index, PUI is Population Using Internet, T-GIC is Total of Information and Communication from Tanzania Mainland and Island.

\subsection{The Control of Industrial Policies to Population using Internet during the Period From 2010 To 2007 in Tanzania}

Information discovered as a result of the investigation shows that relationship between Economic openness and Population Using Internet is Negative and meaningless during the period from 2010 to 2017 in Tanzania. The results show the multiplier of Economic Openness is -0.4858, which means the relationship between Economic openness and Population Using Internet is insignificant in Tanzania. Therefore Industrial policies had no control to Population Using Internet during the period from 2010 to 2017 in Tanzania.

TABLE 1: Regression consequence Between Economic Openness and Information and Communication Gross Domestic Product during the period from 2010 to 2017 in Tanzania. Dependent Variable : TzICGdp

\begin{tabular}{lllll}
\hline $\mathrm{V}$ & $\mathrm{CT}$ & $\mathrm{SD}$ & $\mathrm{T}$ & $\mathrm{P}$ \\
\hline $\mathrm{M}$ & -0.2798 & 0.0572 & -4.8853 & 0 \\
$\mathrm{C}$ & 2.70 & & & 0 \\
$\mathrm{R} 2$ & 0.3637 & & & \\
$\mathrm{AR}$ & 0.2577 & & & \\
S.E.R & 0.1408 & & & \\
NOB $=8$ & & & & \\
\hline
\end{tabular}

Origin: Approximated from Appendix 3

Where by: $\mathrm{V}$ is Variable, CT is Coefficient, $\mathrm{C}$ is Constant, $\mathrm{SD}$ is the Standard Deviation, $\mathrm{T}$ is $\mathrm{T}$-Statistic , $\mathrm{P}$ is Probability, M is Economic Openness , R2 is R-Squared, AR is Adjusted R-Square, SER is Standard Error of Estimation NOB is number of Observation.

Appendix 3: Regression Calculations between Economic Openness Index and Information and Communication Gross Domestic Product during the period from 2010 to 2017 in Tanzania. [ Figures originated from Appendix 2]

\begin{tabular}{llllll}
\hline $\mathrm{Y}$ & EOI & GDP-IC & $\mathrm{X}^{2}$ & $\mathrm{Y}^{2}$ & $\mathrm{XY}$ \\
\hline 2010 & 3.86 & 1.19 & 14.9 & 1.42 & 4.59 \\
2011 & 6.34 & 1.03 & 40.2 & 1.06 & 6.53 \\
2012 & 4 & 1.16 & 16 & 1.35 & 4.64 \\
2013 & 3.88 & 1.28 & 15.05 & 1.64 & 4.97 \\
2014 & 3.81 & 2.01 & 14.52 & 4.04 & 7.66 \\
2015 & 3.71 & 1.99 & 13.76 & 3.96 & 7.38 \\
2016 & 3.57 & 1.95 & 12.74 & 3.8 & 6.96 \\
2017 & 3.47 & 1.87 & 12.04 & 3.5 & 6.5 \\
\hline TOTAL & 32.64 & 12.48 & 139.21 & 20.77 & 49.23 \\
\hline
\end{tabular}

Where by : Y is Year, EOI is Economic Openness, GDP-IC Information and Communication Gross Domestic Product, $\mathrm{X}^{2}$ is Economic Openness Index multiplied by Economic Openness, $\mathrm{Y}^{2}$ is Information and Communication Gross Domestic Product multiplied by Information and Communication Gross Domestic Product, and XY is Economic Openness multiplied by Information and Communication Gross Domestic Product during the period from 2010 to 2017 in Tanzania.

\subsection{Summary of Findings}

Information discovered as a result of the exploration shows that the relationship between economic openness and all digital macroeconomic variable applied by the study (Information and Technology Gross Domestic Product and Population Using Internet) is negative and meaningless. To such a degree industrial policies had no control to the digital 
economy during the period from 2010 to 2017 in Tanzania.

Table 2: Regression consequence Between Economic Openness and Population Using Internet during the period from 2010 to 2017 in Tanzania. Dependent Variable : TzPUI

\begin{tabular}{lllll}
\hline $\mathrm{V}$ & $\mathrm{CT}$ & $\mathrm{SD}$ & $\mathrm{T}$ & $\mathrm{P}$ \\
$\mathrm{y}$ & -0.4858 & 0.3158 & -1.5385 & 0 \\
$\mathrm{C}$ & 3.9571 & & & 0 \\
$\mathrm{R} 2$ & 0.2803 & & & \\
$\mathrm{AR}$ & 0.1604 & & & \\
S.E.R & 0.7760 & & & \\
NOB $=8$ & & & & \\
\hline
\end{tabular}

Origin: Approximated from Appendix 4

Where by: $\mathrm{V}$ is Variable, CT is Coefficient,C is Constant, $\mathrm{SD}$ is the Standard Deviation, $\mathrm{T}$ is $\mathrm{T}$-Statistic, $\mathrm{P}$ is Probability, M is Economic Openness, R2 is R-Squared, AR is Adjusted R-Square, SER is Standard Error of Estimation NOB is number of Observation.

Appendix 4: Regression Calculations between Economic Openness Index and Population Using Internet during the period from 2010 to 2017 in Tanzania. [ Figures originated from Appendix 2].

\begin{tabular}{llllll}
\hline $\mathrm{Y}$ & EOI & $\mathrm{P}-\mathrm{INT}$ & $\mathrm{X}^{2}$ & $\mathrm{Y}^{2}$ & $\mathrm{XY}$ \\
\hline 2010 & 3.86 & 1.06 & 14.9 & 1.12 & 4.09 \\
2011 & 6.34 & 1.16 & 40.2 & 1.35 & 7.35 \\
2012 & 4 & 1.37 & 16 & 1.9 & 5.48 \\
2013 & 3.88 & 1.48 & 15.05 & 2.2 & 5.74 \\
2014 & 3.81 & 1.95 & 14.52 & 3.8 & 7.43 \\
2015 & 3.71 & 3 & 13.76 & 9 & 11.13 \\
2016 & 3.57 & 2.56 & 12.74 & 6.55 & 9.14 \\
2017 & 3.47 & 3.22 & 12.04 & 10.37 & 11.17 \\
\hline TOTAL & 32.64 & 15.8 & 139.21 & 36.29 & 61.53
\end{tabular}

Where by : Y is Year, EOI is Economic Openness, P-INT is Population using internet in Tanzania,, $\mathrm{X}^{2}$ is Economic Openness Index multiplied by Economic Openness, $\mathrm{Y}^{2}$ is Population using internet in Tanzania multiplied by Population using internet in Tanzania, and XY is Economic Openness multiplied by Population using internet in Tanzania during the period from 2010 to 2017 in Tanzania.

\section{Conclusion}

The contemporary study is determined to explore the control of industrial policies to the digital economy specifically macroeconomic digital variables employed by the study (Information and Technology Gross Domestic Product and Population Using Internet) during the period from 2010 to 2017 in Tanzania. Information discovered as a result of the exploration shows that the relationship between economic openness and all digital macroeconomic variable applied by the study (Information and Technology Gross Domestic Product and Population Using
Internet) is Negative and meaningless. To such a degree industrial policies had no control to the digital economy during the period from 2010 to 2017 in Tanzania.

\section{Recommendations}

With reference to the fact that information discovered as a result of the exploration shows that the relationship between economic openness and all digital macroeconomic variable applied by the study (Information and Technology Gross Domestic Product and Population Using Internet) is Negative and meaningless. To such a degree industrial policies had no control to the digital economy during the period from 2010 to 2017 in Tanzania.

The Study offer the following policy recommendations:

Industrial policies must be frequently reviewed to absorb and reflect the current digital economy infrastructure for effective and efficient implementation and sustainable support the digital economy. The making and unmaking of strong and weak industrial policies, understanding policies features formation within information and technology sector to reflect the Tanzania digital economy.

The making and unmaking of strong and weak industrial policies, understanding policies features formation within industrial sector are to support the Tanzania digital economy. Government should consider the complementary of industrial policies, investment policies and digital policies in a perspective of objectives and implementation to achieve the desired goals for quickly economic transformation.

\section{References}

[1]. Okeleke. K. (2019). Digital transformation in Tanzania The role of mobile technology and impact on development goals. GSMA.

[2].Foster. C. and Azmeh.s. (2018). Latecomer Economies and National Digital Policy: An Industrial Policy Perspective. The Journal of Development Studies.

[3]. John (2016). Industry in Tanzania Performance, prospects, and public policy.WIDER Working Paper 2016/5.

[4].Lee, S., Fullerton, V., Yusuf, Y., Krantz, S., and Henstridge, M. (2018). Tanzania Case Study: Rapid Technological Change - Challenges and Opportunities Final Report Salam.

[5].Kweka.J. (2018). Monitoring Policies To Support Industrialization In Tanzania. An Update and Policy Recommendation. Supporting Economic Transformation (SET).Energy Reviews, 90, pp.1060-1068. 
[6].Darkoh. M.B.K. (1984). Tanzania's Industrial Development and Planning Experience. Journal Of Eastern African Research and Development.

[7]. Mwang'onda.S.E ,Mwaseba.S.L. ,Juma. M. S. (2018). Industrialization in Tanzania: The Fate of Manufacturing. Sector Lies upon Policies Implementations. International Journal of Business and Economics Research. Vol. 7, No. 3, 2018, pp. 71-78.

[8]. Sheikheldin, Gussai, Diyamett, Bitrina, Makundi, Hezron (2018). Energy policy for industrialization: Tanzania's big development challenge. Global Development.

[9]. Gray. H. (2013). Industrial policy and the political settlement in Tanzania: aspects of continuity and change since independence. 